\title{
Acceptance Address on the Occasion of the Award of an Honorary Doctorate from the Poznań University of Economics and Business ${ }^{1}$
}

\author{
Michael E. Porter ${ }^{2}$
}

First let me thank all of you for this wonderful recognition and for the generous laudations. As I was listening, I could not help thinking about the history and evolution of my body of work. While my work covers a broad range of fields, it is all connected. Work in one field influences new thinking about others. All my work is based on a broad, systemic view of competition at multiple levels and its impact on societal outcomes. Furthering an understanding of what we need to accomplish in order to drive economic and social progress is my passion, and where I seek to contribute through all of my work.

Today, given limited time, I will talk about just one topic where there is rapidly growing interest and implications for business practice: what should be the role of business in society.

This is a very important question because the world is full of problems: social problems, such as education, health, nutrition, housing, clean water, discrimination, economic problems such as unequal opportunity, low income, and many others. Awareness of these problems has been increasing especially over recent decades.

Traditionally, we have tackled such social problems through two institutions. One, of course, is government. Government's job is to make society better. Second, are NGOs and non-profits which represent a comparatively new sector that was much less significant 50 or 75 years ago. There are countless organisations around the world dedicated to social improvement in specific areas, such as child health, reducing violence, or advancing environmental issues.

${ }^{1}$ The honorary PhD title was awarded to Professor Michael E. Porter by a decision of the Senate of the Poznań University of Economics and Business in 2014. The title award ceremony took place on March 19, 2019 at the Poznań University of Economics and Business.

${ }^{2}$ Institute for Strategy \& Competitiveness, Harvard Business School, Ludcke House, Boston, MA 02163, U.S.A., mporter@hbs.edu. For an overview of Michael Porter's research and career, please see the Institute for Strategy and Competitiveness Website, https://www.isc.hbs.edu/aboutmichael-porter/biography/Pages/default.aspx. 
These organizations exist in every field today, all over the world. NGOs and non-profits have had a major impact on the rising awareness of social challenges.

How are we doing in addressing these? If we are honest, governments and non-profits are making major efforts. However, progress is incremental. Many of the problems that we see all across the world (and the United States is a very good example of problems) are not improving very fast, despite a massive investment of effort and capital on the part of many. I have come to believe that this traditional path alone is not sufficient. It is not working fast enough, it is not scaling rapidly enough given limited resources. In societies, across the world, there are still countless problems to deal with.

This realization led me to the question of where business fits in. We all know that business is the economic driver. This happens when businesses compete to meet customer needs at a profit, which creates jobs, income, a higher standard of living, greater prosperity, and a growing GDP. Business has played this powerful economic role for centuries. However, more people are starting to ask the question: What should business' role be in society? Does it have a role? How does a social role align with profits? These are questions that I, together with Mark Kramer and colleagues at Harvard Business School, are deeply interested in.

I believe strongly that business must contribute broadly, and not just think narrowly of its role as doing business. Business has many assets to bring to bear on driving change-talent, management capacity, capital, and a performance culture. Governments do not have enough money to deal with all of the societal problems we face. NGOs depend on donations, but there are not enough to truly move the needle. Government and NGOs can play a role, but they alone are not the fundamental solution.

Despite the fact that business has important assets for addressing many social problems, trust in business has been eroding. Too many people today think that business is part of the problem, not a solution. There are surely some companies that have been bad actors, furthering their narrow business interests at the expense of society. Another challenge is that many people believe that profit is inherently bad for society-if a business is earning a profit it must be somehow taking away from society.

There has been a major increase in efforts by businesses to have positive social impact, yet society continues to question the value of business. Meanwhile, advocates of socialism are increasing today despite the clear failures of socialism and its devastating effect on societies and on citizen well-being. ${ }^{3}$ Understanding how business can regain its legitimacy is one of the most important challenges business is facing today.

We will need all our institutions to address social challenges as well as create economic prosperity. How can we leverage all of the different institutions

\footnotetext{
${ }^{3}$ Venezuela provides the latest example in a long line of failed socialist states.
} 
for societal progress in a way that does not exclude business, but includes it? And how can business step up what has been a very slow rate of progress on social issues?

There is a long history of business trying to positively impact society, especially in company towns and the paternalistic business practices of the $1800 \mathrm{~s}$ and early 1900s. Over time, however, pressure from investors led most businesses to focus mostly on philanthropy-making donations to worthy causes and volunteering employees' time. Business has the resources, and should make a portion available to other societal institutions to advance our societies. Contributing to social causes is good, and a step in the right direction, but it is not a solution. There is only so much that companies can donate, and investors have been wary of corporate spending that is not connected to the business itself.

However, companies have faced growing external pressures to do more. Most businesses adapted to another approach, called corporate social responsibility. This is the idea that business has a responsibility to positively impact their communities. Corporate social responsibility is about being ethical, compliant with the rules and standards of society, being a good corporate citizen, and acting sustainably.

Broadly, the corporate social responsibility movement is focused on eliminating negative impacts of business. It is about securing business' "license to operate" or acceptance by the community, and reducing the tension between business' goals and society's goals. The focus has been on addressing areas of criticism, and areas where business has been seen as acting in ways that are not in the best interest of communities and societies. This is a step forward, but reducing negative impacts alone is not a true solution to societal challenges. Positive contribution is required.

A more powerful role for business in addressing social issues is needed. Defining this new role for business is a topic where I have devoted major attention. With co-author Mark Kramer, I published a paper called "Creating shared value" in 2011 (Porter \& Kramer, 2011). The fundamental concept is the idea that businesses will create the greatest social impact where it can address societal issues with a profitable business model. This is a powerful approach not just for solving societal problems, but also drives improvement and innovation in the business itself.

Importantly, if a company can develop products or services that advance social problems in a way that is profitable for the business (e.g. reducing energy use), the social impact is scalable and sustainable, a major flaw in the NGO and government model. For example, if a company can innovate to develop a product that uses fewer raw materials and less energy to produce and is equivalent on other dimensions, many customers will buy the environmentally friendly product. This is the most powerful way business can benefit society, because it creates the opportunity for real solutions on a large scale. 
Since the idea of shared value was introduced in 2011, more and more companies have embraced this idea in many parts of the world. Business leaders have begun to realize that making a profit at the expense of society undermines business, but making a profit while advancing an important social need will change the world.

An obvious question is how can business do this? Many economists and business leaders still believe that improving social conditions reduces profitability. We found that it is actually the opposite. If we can improve water or energy usage, sell more nutritious products, avoid accidents, and avoid pollution, we often actually increase profit.

We must overcome embedded economics thinking that profit and positive social impact are inconsistent. For many years, for example, economists thought that it was profitable for a company to pollute, and strict environmental regulations were needed to stem pollution. The reality is that pollution is more expensive for a company in many cases. If a company lowers pollution, it reduces waste. If it fails to use raw materials or water efficiently, it wastes resources. Companies that are not energy efficient are driving up costs. This has been challenging for many economists to accept, and sparked great debate, but research overwhelmingly supports this relationship.

Imagine if businesses were not just giving money and apologizing for adverse impacts in the past. What if, instead, businesses were innovating in improving nutrition, providing affordable housing, and producing low cost, energy efficient products? If we could start moving further in these directions, there is an opportunity for real solutions, solutions that can grow and scale over time.

How can companies create shared value? First, shared value is created through the company's products and the customers it serves. Shared value asks: is a product meeting an important social need, such as improving nutrition, not just an economic need? Is a product or service meeting important needs of unserved customers, such as lower-income families that cannot typically afford many products? Shared value products open up new markets and revenue and profit growth, but also benefit society.

A second means of creating shared value is by rethinking how to operate a business. Traditionally many thought that social issues like the environment or health care were not important considerations in company operations. Now we understand that some of our greatest costs come from social deficits. For example, poor employee health often leads to absenteeism and lack of worker retention, which drives up cost and reduces profits.

The third way companies can create shared value is to recognize that the success of their business is actually dependent on access to a vibrant ecosystem where the company operates. Investments that improve local rules and practices, infrastructure, education, workforce skills and so on, make the business more effective. For example, by helping companies recruit better people, or procure higher quality inputs from local sources. 
What progress have we seen since the idea of shared value was first introduced? Initially, there were some that doubted the connection between economic success and social success. Over time, however, more and more companies have realized that shared value is possible, and begun to innovate. There are now companies that have embedded this thinking deeply in their strategy, and achieved major economic success while advancing society and their communities. The Fortune Change the World List, published annually, recognises companies that are making major social impact through shared value. ${ }^{4}$ The most successful companies of the future will be those that can compete this way.

Walmart is among the most powerful shared value examples. It is the world's largest company, a broad-line discount retailer with very low prices. Walmart was one of the most criticized companies in America because its bargaining power put some small businesses and small shopkeepers out of business. Walmart also negotiated hard with suppliers to reduce cost to support their low cost strategy. Walmart was also criticized for lower wages, not providing adequate health insurance, and many other areas.

What does Walmart look like today? It has shifted from looking at itself narrowly as a business, to thinking broadly in terms of how it can influence the challenges society faces (Porter \& Ramirez-Vallejo, 2017). Walmart sells more organic, fresh, and healthy food than any other retailer in the world, at much lower average prices. Walmart locates stores in communities that lack other efficient food stores, called "food deserts," as a means for residents to access healthy food. Walmart also offers very low-cost financial services, much less costly than dealing with other financial organizations, to bring financial services to previously unserved populations.

Health care is high-cost and not accessible to low-income people, so Walmart now offers very low-cost health services in its stores all across America. Walmart also estimates that it has saved American consumers approximately five billion dollars on prescription drugs, while still being profitable.

Walmart believes in local sourcing, which lowers logistical costs and also contributes to the community and its local businesses. Walmart understands that the company will have a better opportunity to grow if its local community and local businesses are advancing. Walmart has made sustainability a major cost reduction tool. It has significantly reduced the energy use and emissions in its operations and logistics, resulting in billions of dollars in savings. Walmart also works closely with its suppliers to ensure they protect the environment, improve quality and have sustainable output.

In human resources, Walmart has understood that paying low wages often does not lower costs. If workers are not well trained or have low retention, co-

\footnotetext{
${ }^{4}$ See the Fortune Change the World list, published annually since 2015: https://fortune. com/change-the-world/.
} 
sts increase. Walmart became a leader in creating good jobs, training and career trajectories for lower-income, lower-skilled workers, creating loyal staff and a better long-term outcome than paying the minimum wage.

Walmart, then, has probably had a greater positive impact on important social issues than many governments. Why? Because they do it efficiently, keep innovating, and are motivated by improving profitability.

Shared value creates a self-reinforcing capitalist system. It is a system in which business generates social benefit and social welfare, and does so at a profit which enables scale and growth. More and more businesses in the U.S. and elsewhere are becoming part of this self-reinforcing path for society, fuelling their competitive advantage and growth.

Poland has examples of shared value. Danone, for example, is a milk-products-and-yogurts company, which led the establishment of a partnership with Instytut Matki i Dziecka to prevent undernourishment in young children (Krzyżanowska \& Tkaczyk, 2014). Many children in Poland and around the world do not get the nutrition needed to properly grow and prosper. Danone's partnership identified ways to improve nutrition in a cereal product that Polish children already ate. The product, Milky Start, fortified with vitamins and other nutritional benefits, is an innovation that targets kids with a product they like at very low cost, and educates parents to provide the children with good nutrition. This successful product is the essence of shared value.

Danone has sold 50 million units of Milky Start and is investing in new products that will have similar benefits. Danone is not a company narrowly maximising profits, but a company thinking more broadly about how to compete in a way that differentiates the company by creating benefit not just for the company, but also for consumers and society.

Shared value thinking is spreading in the corporate world, now that companies have overcome conventional thinking. And, more and more investors are looking at companies and asking the question: "Does this company benefit society, not just make money?" Investors are recognizing the potential of companies where they see shared value.

All over the world, governments and other institutions are struggling to address the social needs we face. This is the problem of our age. As scholars, we are obligated to take on the big questions of how to change this. Our purpose should not be just to write papers for peers in our discipline, but to connect with what is happening in the world, and how we can contribute.

Many in academia focus primarily on advancing their discipline, not advancing society. We as scholars and professors must aspire to have more impact on the world. Let us as professors no longer just talk to each other and our students, but engage in the world in the ways it works in practice. The world is messy; it does not fit neatly in mathematical models. The more we at universities can engage in actual practice in our areas of expertise, the faster we will start to see society advancing. 


\section{References}

Fortune Change the World list, published annually since 2015. Retrieved from https:// fortune.com/change-the-world/

Krzyżanowska, M., \& Tkaczyk, J. (2014). Shared value creation and marketing. Management and Business Administration. Central Europe, 127(4), 153-167.

Porter, M. E., \& Kramer, M. (2011). Creating shared value. Harvard Business Review, 89(1/2), 62-77.

Porter, M. E., \& Ramirez-Vallejo, J. (2017). Walmart: Navigating a changing retail landscape. Case study. Boston: Harvard Business Publishing. 